Anna Ambrochowicz-Gajownik

Światowa Rada Badań nad Polonią, Olsztyn

ORCID ID: 0000-0001-7460-0859
OBLICZA WOJNY

TOM $3 \cdot$ MIASTO I WOJNA

ŁÓDŹ2021 • ISBN 978-83-8220-556-5 • s. 195-208

https://doi.org/10.18778/8220-556-5.11

\title{
OŚRODKI MIEJSKIE POŁUDNIOWEJ FRANCJI MIEJSCEM SCHRONIENIA DLA POLSKICH UCHODŹCÓW W LATACH 1939-1940
}

Streszczenie. Południe Francji stało się ważnym ośrodkiem schronienia dla uchodźców cywilnych i wojskowych. Działania władz polskich objęły swym zasięgiem liczbę przeszło 5000 uchodźców z Polski, a także zdemobilizowanych żołnierzy, których było 12 tys. Ewakuacja do Francji odbywała się drogą morską oraz lądową. Od października 1939 r. do kwietnia 1940 r. przeszło przez punkty graniczne 31727 osób. Do maja 1940 r. ewakuowano 33120 osób. W różnych ośrodkach południa Francji dla uchodźców utworzono specjalne schroniska, kuchnie, zaś niektórych umieszczano w hotelach. Postarano się również stworzyć świetlice oraz małe zakłady pracy. Polskim żołnierzom i ich rodzinom udzielono ponadto wszelkiej pomocy. Zaopiekowano się także emigracją przedwojenną. Pozyskanie miejsc schronienia dla uchodźców nie byłoby możliwe bez współpracy z miejscowymi władzami. Kluczową rolę w opiece nad uchodźcami w tym okresie odegrały polskie placówki konsularne, działające do września 1940 r., oraz delegatury Polskiego Czerwonego Krzyża, utworzone w Tuluzie, Marsylii, Nicei. Klęska Francji przyniosła zmianę zarówno dla rządu polskiego, jak i uchodźców.

Słowa kluczowe: Prowansja - Lazurowe Wybrzeże, Tuluza, polska służba konsularna, stosunki polsko-francuskie, Polski Czerwony Krzyż, druga wojna światowa

Klęska wrześniowa Polski i wynikająca z niej ewakuacja rządu polskiego przez Rumunię do Francji spowodowała wewnętrzny chaos nie tylko wśród elit politycznych, lecz także ludności cywilnej. Najwyższe władze państwowe, internowane w Rumunii, nie mogły kontynuować swej pracy we Francji. Władzę przejęła nowa ekipa na czele z Władysławem Sikorskim ${ }^{1}$. Francja, przyjmując

${ }^{1}$ H. Batowski, Polska dyplomacja na obczyźnie 1939-1941, Kraków 1991, s. 55-58; S. ZABIEŁŁO, O rząd i granice. Walka dyplomatyczna o sprawe polską w II wojnie światowej, Warszawa 1986, s. 32-39; T. Wyrwa, Bezdroża dziejów Polski. Kraj i emigracja po 1 września 1939 r., Lublin 2000, 
i zapewniając bezpieczeństwo ukonstytuowanemu 30 września 1939 r. rządowi polskiemu, stała się dla obywateli polskich ośrodkiem schronienia. Wcześniej, 7 września 1939 r. minister spraw zagranicznych Georges-Étienne Bonnet i ambasador Juliusz Łukasiewicz podpisali umowę finansową, którą zatwierdził dekretem z 9 września prezydent Francji Albert Lebrun. Dzięki temu dokumentowi Polsce przyznano na czas wojny środki na pokrycie kosztów prowadzenia ambasady i konsulatów we Francji. Polska otrzymała do 30 czerwca 1940 r. sumę 20511956 franków francuskich (dalej: fr.fr.).

Warto jednak wspomnieć, że w chwili wypowiedzenia przez Francję wojny Niemcom 3 września, a następnie podpisania układu politycznego z Polską 4 września, kolejnym wspólnym dokumentem był układ wojskowy z 9 września o utworzeniu polskich jednostek wojskowych na terenie Francji. Łukasiewicz wzywał rodaków na ziemi francuskiej, by wstępowali w szeregi wojska. Dnia 4 stycznia 1940 r. podpisano kolejny układ o formowaniu armii polskiej we Francji, do której mieli wstępować ochotnicy, rezerwiści, poborowi, oficerowie. Miesiąc później, 14 lutego, została podpisana polsko-francuska umowa o organizacji polskiego lotnictwa we Francji, które miało się ćwiczyć i szkolić pod dowództwem polskim, wykorzystując francuski sprzęt.

Zainteresowania rządu polskiego we Francji, poza sprawami wojskowymi, skupiały się na kwestiach związanych z organizacją opieki nie tylko dla starej emigracji, ale także dla napływających uchodźców cywilnych oraz wojskowych. Strona francuska popierała tę akcję, spodziewając się wymiernych korzyści z faktu przybycia na ich terytorium osób doświadczonych w kampanii 1939 r., a także specjalistycznych kadr. Rząd francuski zakładał również ewakuację osób przydatnych dla francuskiego rolnictwa i przemysłu, co też skutkowało w późniejszym czasie niemożnością wyreklamowania pewnej grupy Polaków z pracy w tych gałęziach gospodarki na rzecz służby w Armii Polskiej².

Od 1939 r. w głównych ośrodkach miejskich na południu Francji rozpoczęła się akcja organizowania schronisk przy współpracy przedstawicieli polskiego rządu oraz prefektur. Miejscowe władze francuskie były wówczas przychylnie nastawione do niesienia pomocy w organizowaniu różnego rodzaju miejsc

\footnotetext{
s. 13-25; A. Ambrochowicz-GAJOWNiK, W cieniu Lazurowego Wybrzeża. Konsulat polski w Marsylii 1919-1940, Warszawa 2019, s. 168.

2 M. Gmurczyk-Wrońska, Polska - niepotrzebny aliant Francji? (Francja wobec Polski w latach 1938-1944), Warszawa 2003, s. 186-190.
} 
schronienia, niemniej jednak sugerowały, ażeby większość uchodźców lokować w ośrodkach miejskich posiadających szeroką ofertę hoteli czy pensjonatów, położonych bliżej Lazurowego Wybrzeża, głównie w okolicach Nicei czy Monaco ${ }^{3}$.

Warto przypomnieć, że ewakuacja uchodźców do południowych ośrodków miejskich odbywała się drogą morską oraz lądową. Port marsylski był w tym czasie głównym punktem komunikacyjnym, do którego zawijały statki z polskimi uchodźcami wojskowymi i cywilnymi. Ewakuowani przybywali do Francji drogą morską z Jugosławii, Grecji, Rumunii, Węgier, Libanu, Algierii, Senegalu, zaś lądową początkowo przez Włochy do Modeny. Zanotowano, że od października 1939 r. do kwietnia 1940 r. przeszło przez punkty graniczne 31727 osób. Do maja 1940 r. ewakuowano 33120 osób $^{4}$.

Jak zatem przedstawiał się obraz polskich uchodźców w pierwszych miesiącach spędzonych na południu Francji? W głównym mieście portowym - Marsylii znajdowały się dwa schroniska dla kobiet i dzieci zorganizowane przez siostry szarytki i franciszkanki. Opieka nad tymi osobami pozostawała w gestii służby konsularnej, która pokrywała koszty dziennego utrzymania w wysokości 12 fr.fr. za osobę, łącznie z wyżywieniem. W departamencie Drôme w miejscowości Buis-les-Baronnies, w Hotelu Luxemburg udało się umieścić początkowo 15 osób, a już w 1940 r. liczba ta zwiększyła się do 50. Według obliczeń polskich konsulatów, w południowych ośrodkach miejskich przebywało od 300 do 900 uchodźców cywilnych. Od czerwca 1940 r. przeważającą liczbę stanowili już żołnierze z rozwiązywanych jednostek. Najważniejsze skupiska znajdowały się w Marsylii i jej okolicach, lącznie z obozem wojskowym w Carpiagne oraz w departamentach Gard i Vaulcuse, w których przebywała przedwojenna emigracja polska lub też ewakuowana z północnych terenów Francji. Departamenty Gard i Bouches-du-Rhône skupiały najwięcej emigrantów (w liczbie 1427) oraz uchodźców (2270). Nie zmienia to jednak faktu, iż wytężona praca polegająca na organizowaniu pomocy uchodźcom nie zawsze była w wystarczająca pod względem kwot wypłacanych zapomóg czy liczby miejsc noclegowych5'

W kontekście uporządkowania sprawy legitymizacji pobytu obywateli Rzeczypospolitej na ziemi francuskiej niezmiernie ważne z punktu widzenia strony

3 A. Ambrochowicz-Gajownik, op. cit., s. 168.

${ }^{4}$ Instytut Polski i Muzeum im. Generała Władysława Sikorskiego w Londynie (dalej: IPMS), Armia Polska we Francji, sygn. A.IV.4/1/37. Przepływ ewakuowanych przez punkty graniczne, k. 90.

5 A. Ambrochowicz-Gajownik, op. cit., s. 169-171. 
francuskiej było w prowadzenie zarządzenia, w którym polscy uchodźcy cywilni, wojskowi, a także poborowi musieli mieć w paszporcie, prócz wizy do Francji, jeszcze odcisk lewego kciuka. Dodatkowo wszyscy uchodźcy przybywający do Francji po 19 września 1939 r. musieli wyrobić paszporty z wizą wystawioną przez właściwe władze francuskie. Następnie, po 15 kwietnia 1940 r., francuska biurokracja w obawie przed osobami niepożądanymi wydała kolejne obostrzenie w sprawie przybywających do Francji Polaków, a mianowicie w każdym paszporcie na 16 stronie wstawiano kropkę. Było to podyktowane wykryciem przypadków korzystania z fałszywych paszportów, którymi legitymowali się Polacy.

Przełomowym momentem wywołującym wśród polskich uchodźców, ale także rządu polskiego, niepokój i strach, była klęska Francji w czerwcu 1940 r. $^{6}$ Wiara w potęgę militarną Francji legła w gruzach. Kluczowym momentem było zajęcie przez Niemców Paryża 14 czerwca. Tego samego dnia prezydent Władysław Raczkiewicz, na posiedzeniu Rady Ministrów, podjął decyzję o ewakuacji polskich władz na Wyspy Brytyjskie, w efekcie uzyskania od rządu brytyjskiego oficjalnego droit de résidence ${ }^{7}$. Najwyższe władze polskie przybyły do Londynu 21 czerwca 1940 r., gdzie zostały powitane przez króla Jerzego VI, w obecności Edwarda Raczyńskiego, ambasadora RP w Londynie ${ }^{8}$. Ewakuacja rządu nie oznaczała wyjazdu wszystkich przedstawicieli dyplomatycznych. Wiązało się to bezpośrednio z potrzebą zorganizowania opieki nad pozostałą na ziemi francuskiej ludnością cywilną oraz wojskowymi, a także podjęciem działań w celu ich ewakuacji. Raczkiewicz prace te powierzył Stanisławowi Kotowi i gen. Marianowi Kukielowi9. Pierwszy z nich miał się zająć ewakuacją cywilów, zaś drugi - wojskowych. Formalne zapewnienie uchodźcom opieki miało na celu uspokojenie wśród nich nastrojów, ponieważ sukcesy armii niemieckiej wywoływały uczucia niepokoju, niepewności czy wręcz paniki. Do wytworzenia takiej atmosfery niewątpliwie przyczyniała się także świadomość, że ich udręka wynikająca z faktu opuszczenia ojczyzny miała się ponownie nasilić w związku z perspektywą dalszej tułaczki. Ponadto w tragicznej sytuacji znaleźli się ci, którzy przebywali w północnych departamentach Francji zajętych przez Niemcy.

6 Vide: M. GMURCZYK-WrońsKA, op. cit.

7 M. PESTKOWSKA, Za kulisami rządu polskiego na emigracji, Warszawa 2000, s. 43.

${ }^{8}$ K. Kania, Edward Bernard Raczyński 1891-1993. Dyplomata i polityk, Warszawa 2014, s. 194; T. Wyrwa, Wtadze RP we Francji. Odbudowa wtadz Rzeczypospolitej w Paryżu i Angers wrzesień 1939-czerwiec 1940, [w:] Wtadze RP na Obczyźnie podczas II wojny światowej 1939-1945, red. Z. BŁAŻYŃSKI, Londyn 1994, s. 71.

9 T.P. RutKowski, Stanistaw Kot 1885-1975. Biografia polityczna, Warszawa 2000, s. 163. 
Z chwilą rozpoczęcia ewakuacji rządu na Wyspy Brytyjskie najpilniejszą sprawą stało się roztoczenie opieki nad emigracją przedwojenną, przebywającą w strefie okupowanej i nieokupowanej (państwa Vichy), oraz napływającymi stale uchodźcami cywilnymi, a także żołnierzami. Do momentu zakończenia działań wojennych opiekę nad Polakami sprawowały polskie konsulaty na terenie Francji, organizacje społeczne oraz Ministerstwo Opieki Społecznej. Niemniej jednak po zajęciu Paryża przez Niemców oraz podpisaniu 22 czerwca 1940 r. rozejmu i przyjęciu warunków niemieckich, kwestią czasu było zamknięcie polskich konsulatów we Francji ${ }^{10}$. Zanim jednak doszło do tego wydarzenia, na posiedzeniu Rady Ministrów 17 czerwca 1940 r. podjęto decyzję o określeniu zasad i charakteru pomocy dla obywateli polskich, którzy przebywali we Francji ${ }^{11}$. Upoważnienie do zorganizowania akcji pomocowej otrzymał z rąk premiera Sikorskiego Feliks Chiczewski, po uzgodnieniach z marszałkiem Philippem Petainem i ambasadorem Howardem Kennardem.

Niespełna dwa dni później, 19 czerwca 1940 r., przystąpiono do utworzenia organizacji, której celem miała być pomoc i organizacja opieki dla obywateli polskich przebywających jeszcze we Francji. Na konferencji w biurze Prezydium Rady Ministrów w Libourne, pod przewodnictwem ministra Stanisława Kota, zdecydowano powołać Komitet Pomocy Polakom we Francji. Następnie minister Kot zaproponował, aby w zakres obowiązków Komitetu weszło udzielanie pomocy zarówno dla byłych wojskowych, jak i ludności cywilnej. Ustalono, że część środków pieniężnych zostanie przeznaczona na nawiązanie kontaktów z ludnością polską oraz na odbudowę struktur polskiej emigracji we Francji. Na siedzibę Komitetu, na blisko dwa miesiące, wybrano lokal konsulatu w Tulu$z_{i e}{ }^{12}$. Komitet miał działać na szerszą skalę niż funkcjonujące jeszcze konsulaty na południu Francji, zważywszy, że ograniczano już działalność służby konsularnej, czego dowodem miała być ogłoszona powszechna ewakuacja urzędników dyplomatyczno-konsularnych ${ }^{13}$.

10 A. Hall, Naród i państwo w myśli politycznej Charles'a de Gaulle’a, Warszawa 2005, s. 113; R. Vinen, France 1934-1970, New York 1996, s. 33-35.

11 A. Pachowicz, Towarzystwo Opieki nad Polakami we Francji 1941-1944, Toruń 2013, s. 25.

12 Ibidem, s. 26.

13 T.P. RutKowski, op. cit., s. 169. Według autora działalność służby konsularnej wobec uchodźców polskich była w tym czasie znikoma, a cytowane przez niego sprawozdania Prezydium RM wskazują nawet, iż nie było jej wcale. Najnowsze badania prowadzone w omawianym zakresie, 
Dnia 28 czerwca 1940 r. w Tuluzie ukonstytuował się zarząd Komitetu Polskiego Czerwonego Krzyża (dalej: PCK) we Francji, którego prezesem został Feliks Chiczewski. Z racji szeregu zadań stojących przed wspomnianą organizacją i ich zakresu terytorialnego, powołano terenowe Delegatury Okręgowe w Lyonie, Tuluzie, Marsylii, Nicei ${ }^{14}$. Na delegatów PCK wybrano nieprzypadkowe osoby. Powierzenie tak odpowiedzialnych funkcji przypadło tym osobom, które charakteryzowały się bogatym doświadczeniem życiowym i zawodowym, a także znajomością środowiska miejskiego, w którym przyszło im działaćl ${ }^{15}$. W Tuluzie funkcję delegata pełnił Zdzisław Wydat, bardzo dobrze znany Stanisławowi Zabielle, cieszący się ogólnym zaufaniem. W Marsylii zaś delegatem został Witold Obrębski, długoletni konsul RP w Marsyliii ${ }^{16}$. Ten ostatni doskonale znał tamtejszy teren, jak również władze miejscowe. Bardzo szybko odniósł sukces, wykorzystując swoje znajomości w Marsylii, dzięki którym udało się zająć opuszczony szpital angielski z pełnym urządzeniem; kierownictwo nad nim powierzono dr. Nawrotnemu. Trzeba jednak dodać, że zdaniem S. Zabiełły, W. Obrębski, mimo pozytywnych cech organizacyjnych, miał skłonność do licznych intryg ${ }^{17}$.

Warto wspomnieć, że po klęsce Francji, na prośbę marszałka Philippe’a Pétaina, kierownictwo ambasady RP w charakterze chargé d'affaires objął 18 lipca Feliks Frankowski, zaś Aleksander Kawałkowski pełnił funkcję radcy emigracyjnego ambasady i otrzymał od Frankowskiego mandat w celu łączności z PCK i z prawem udziału w zebraniach Prezydium. We wspomnieniach S. Zabiełly wyraźnie widać, że stosunki z A. Kawałkowskim i F. Frankowskim niezbyt dobrze sięukładały ${ }^{18}$.

Roztoczenie opieki nad uchodźcami nie było wcale sprawą łatwą ze względu na piętrzące się problemy finansowe. Frankowski zwracał baczną uwagę, aby oszczędnie dysponować funduszami. Ponadto zabiegał o zacieśnienie relacji

\footnotetext{
czego dowodzi m.in. treść niniejszego artykułu, prowadzą do konstatacji, iż pogląd ten należy uznać za zdezaktualizowany.

${ }^{14}$ IPMS, Polski Czerwony Krzyż we Francji (dalej: PCK), sygn. PRM-K/6, Polski Czerwony Krzyż do Zarządu Głównego P.C.K. w Londynie, Vichy 18 IX 1940 r., k. 22-35; A. PACHOwicz, op.cit., s. 27.

15 S. ZabieŁeO, Na posterunku we Francji, Warszawa 1967, s. 113.

16 Vide: A. Ambrochowicz-Gajownik, op. cit.

17 S. ZABIEEEO, op. cit., s. 113-114.

18 Ibidem, s. 124-126.
} 
pomiędzy PCK a konsulatami działającymi na południu Francji - w Marsylii, Tuluzie i Nicei - w celu skoordynowania działań opiekuńczych ${ }^{19}$. Zaznaczył, że jedyną formą pomocy materialnej jest opieka zbiorowa organizowana przez PCK, zapewniająca wyżywienie oraz mieszkanie w schroniskach. Pomoc ta płynęła głównie do osób pozbawionych środków do życia, niemających pracy oraz podupadłych na zdrowiu. Uchodźcy przybywający do terenowych delegatur musieli uprzednio otrzymać zaświadczenie z konsulatu, iż oddaje ich pod opiekę PCK. Warto jednak podkreślić, że owe zaświadczenia nie było wiążące dla $\mathrm{PCK}^{20}$. Konsulaty miały udzielać pomocy osobom wywodzącym sięze starej emigracji, jednak w sposób bardzo oszczędny, i raczej kierować je do zarządu Związku Polaków we Francji. Następnie od sierpnia konsulaty miały udzielać pomocy wojskowym ${ }^{21}$.

Zanim jednak PCK rozpoczęło swoją działalność oraz współdziałanie z konsulatami, te drugie roztaczały opiekę nad uchodźcami we własnym zakresie. Konsulat w Marsylii żalił się, że środki finansowe, jakimi dysponował w kwocie 100 tys. fr.fr., były niewystarczające, a pomoc z PCK znikoma. Warto nadmienić, że faktyczny rozmach działań PCK nastąpił dopiero od sierpnia 1940 r. W międzyczasie placówka marsylska przyjęła na swoje barki główny ciężar organizowania pomocy dla uchodźców, zapewniając im noclegi w asile de nuit (schronisku) oraz wydając bony na żywność. Ze strony francuskiej również nie płynęła pomoc finansowa w postaci zapomóg. Niemniej jednak i tak sporym sukcesem było uzyskanie miejsca w hotelach, szkołach, pensjonatach czy schroniskach udostępnianych przez Francuzów. Z budżetu konsulatu utrzymywane były także dwa schroniska u sióstr franciszkanek i szarytek (32 osoby) oraz w Buis-les-Baronnies (15 osób). Dzienne wydatki konsulatu dla uchodźców i żołnierzy wynosiły 7 tys. fr.fr. ${ }^{22}$

19 IPMS, PCK, sygn. PRM-K/6, Pismo Ministerstwa Spraw Zagranicznych w Londynie, Londyn 13 IX 1940 r., k. 9; Archiwum Akt Nowych (dalej: AAN), Konsulat RP w Marsylii (dalej: KRPM), sygn. 464/916, PCK do Konsulatu RP w Marsylii, Tuluza 15 VIII 1940 r., k. 30; Biblioteka Polska w Paryżu (dalej: BPP), Archiwum Polskiego Czerwonego Krzyża we Francji ze spuścizny Józefa Jakubowskiego (dalej: PCK SJJ), sygn. 22, Ambasade de Pologne do Panów Konsulów Generalnych RP w Marsylii, Tuluzie, Nicei, Lyonie, Vichy 8 VIII 1940 r., k. 41-42.

${ }^{20}$ Ibidem, Instrukcja: Podział kompetencji między konsulatami a PCK, k. 46-50.

${ }^{21}$ Ibidem, Feliks Chiczewski do Witolda Obrębskiego delegata PCK, Tuluza 8 VIII 1940 r., k. 67.

${ }^{22}$ Ibidem, konsul generalny dr Adam Lisiewicz do Ambasady RP w Vichy, Marsylia 24 VII 1940 r., k. 63. 
Po ustaleniu od sierpnia 1940 r. zakresu kompetencji między konsulatami a PCK, sytuacja zaczęła się stabilizować. Dla służby konsularnej zarząd PCK wyasygnował 200 tys. fr.fr. Konsulat w Tuluzie otrzymał 90 tys. fr.fr., w Marsylii 600 tys. fr.fr. ${ }^{23} \mathrm{~W}$ efekcie przekazania tych środków rozpoczęto natychmiastową akcję pomocową, co przełożyło się na liczbę około 1000 osób, które uzyskały wsparcie; w okręgu marsylskim - 2 tys., zaś najwięcej w Tuluzie -7 tys. osób. Zorganizowano wówczas przejściowe punkty noclegowe oraz kuchnie, w których wydawano bezpłatne lub w niskiej cenie obiady, w cenie od 4 do 6 fr.fr. Kuchnie powstały w Tuluzie, Marsylii, Nicei, Lourdes, Salies-du-Salat.

Niezmiernie ważne było współdziałanie delegatur i konsulatów z władzami lokalnymi. Kiedy władze francuskie przeniosły się do Vichy, zarząd PCK zwrócił się o przyznanie polskim uchodźcom zasiłków na takich samych zasadach, na jakich wypłacano je obywatelom francuskim. Był to tzw. dekret alokacyjny. Zakładał on wypłacanie niewielkich sum pieniężnych. Ustalony był głównie dla Francuzów i Belgów, zaś dla Polaków opierał się na oświadczeniu Ministra dla Uchodźców. Nie była to jednak formalna umowa, z której rząd francuski miał obowiązek się wywiązać. Alokacja wypłacana była przez urzędy gminne. Obejmowała listę uchodźców tzw. stałych - na podstawie zamieszkania i przydziału miejsca zamieszkania według list i legitymacji, oraz przejściowych - według list numerycznych (ilościowych). Rząd Vichy początkowo podchodził do tego pomysłu sceptycznie, jednak ostatecznie wyraził zgodę na wypłacanie zasiłków. Największa ich liczba pobierana była w departamencie Haute Garonne, na Riwierze zaś w mniejszym stopniu (departament Var, Bouches-du-Rhône, Alpes Maritimes), ponieważ tam łatwiej było uzyskać miejsce w schroniskach i otrzymać wyżywienie. Zdarzały się przypadki, kiedy merowie odmawiali wydawania zasiłków alokacyjnych. Wówczas taki problem należało niezwłocznie zgłosić do prefektury, a jego rozwiązaniem zajmowało się PCK. Stanisław Zabiełło wspomina, że wypłacano zasiłki ze środków PCK, a wartość tych świadczeń strona francuska pokrywała w czasie późniejszym ${ }^{24}$.

Działania władz polskich objęły swym zasięgiem ponad 5 tys. uchodźców z Polski, a także zdemobilizowanych żołnierzy, których liczbę szacowano na

23 BPP, PCK SJJ, sygn. 22, PCK do Ambasady RP w Vichy, Tuluza 8 VIII 1940 r., k. 53.

${ }^{24}$ S. ZABięeO, op. cit., s. 111; A. PACHOWICZ, op. cit., s. 29, według autorki władze francuskie w Tuluzie przestały wypłacać świadczenia z dniem 1 X 1940 r., zaś w innych departamentach akcja trwała znacznie dłużej. 
około 12 tysięcy. Ci potrzebowali natychmiastowej pomocy, ponieważ groziły im obozy pracy. Wsparciem zostały objęte osoby z rodzin urzędników, rodziny jeńców z kampanii wrześniowej, oficerów ewakuowanych do Anglii oraz wojskowych przybyłych z Polski, a wziętych do niewoli niemieckiej po czerwcu 1940 r. Następnie pomocą objęto 300 inżynierów sprowadzonych specjalnie z Rumunii i Węgier dla potrzeb przemysłu wojennego, a którzy pozostawali wówczas bez środków do życia. Ostatnią grupą byli pozostający bez pracy urzędnicy ministerstw i placówek konsularnych. Kolejnym etapem działalności było roztoczenie opieki nad osobami starszymi, a także zorganizowanie szkolnictwa ${ }^{25}$. W połowie sierpnia 1940 r. oszacowano, że na akcję pomocy dla uchodźców, stałej emigracji, zdemobilizowanych, pracowników umysłowych i rodzin potrzebna była wcale niemała suma $-8 \mathrm{mln}$ fr.fr. ${ }^{26}$

Istotną kwestią było zadbanie o zapewnienie pomocy medycznej, zwłaszcza bezpłatnej. Przedstawiciele władz polskich walczyli, aby koszty nagłych przypadków, jak operacje, pokrywane były ze środków francuskich. Zabiegi o to nie były łatwe, ale znacznie ułatwiły pracę przy rozdzielaniu środków na inne równie ważne cele. Pacjent, aby mógł zostać zoperowany na koszt francuskiego skarbu, musiał otrzymać uprzednio zaświadczenie z prefektury lub merostwa, natomiast w lżejszych przypadkach chorzy umieszczani byli w szpitalach francuskich bez ponoszenia opłat ${ }^{27}$.

Zapoczątkowana została także akcja organizowania świetlic, dzięki którym kształtował się wśród uchodźców duch jedności narodowej. Najwięcej świetlic powstało w Tuluzie, bo aż cztery. Ważną inicjatywą było zorganizowanie opieki duszpasterskiej w Tuluzie, Salies-du-Salat i Lourdes. Udało się również utrzymać stare schroniska i utworzyć nowe - w liczbie 15, z czego 9 już funkcjonowało, a 6 zostało otwartych. W Juan-les-Pins otworzono schronisko dla 150 osób. Znajdowały w nim schronienie rodziny wojskowych, zwłaszcza żony wojskowych przebywających w niewoli lub w Anglii. Poczyniono także starania, aby uruchomić we własnym zakresie małe zakłady pracy, które dawały zatrudnienie. W Nicei powstała pracownia trykotażowa, w Tuluzie zaś zorganizowano akcję zbierania odpadków, w celu ich przetworzenia.

${ }^{25}$ IPMS, PCK, sygn. PRM-K/6, Ambasade de Pologne do Ministerstwa Spraw Zagranicznych w Londynie, Vichy 15 VIII 1940 r., k. 10-12.

26 BPP, PCK SJJ, sygn. 22, PCK do Ambasady RP w Vichy, Tuluza 8 VIII 1940 r., k. 53.

${ }_{27}$ Ibidem, sygn. 6, Instrukcja nr 6: Pomoc lekarska, Tuluza sierpień 1940 r., k. 209. 
Po klęsce Francji nastąpiła zmiana nastawienia władz francuskich wobec Polaków, nawet tych ze starej emigracji. Celem urzędników administracji lokalnej stało się utrudnianie pobytu na południu. Francuzi zasłaniali się wtenczas odgórnymi decyzjami płynącymi od władz niemieckich. W Marsylii i Nicei rozpoczęło się chasse au lapin - polowanie na króliki, do tego stopnia, że przesłuchiwano w prefekturze nawet polskie dzieci, pytając je o status materialny rodziców. Przy załatwianiu wszelkich spraw formalnych priorytetem dla miejscowych władz stało się, aby cudzoziemcy, w tym Polacy, mieli już jakieś zabezpieczenie materialne,. Ponadto otrzymanie przez uchodźców visa de sortie - wizy wyjazdowej, nie było wcale łatwe, zaś zezwolenie na pobyt na południu Francji wystawiane było na krótki okres. Na kilka miesięcy Francja zaprzestała wymagać od cudzoziemców legitymowania się kartami tożsamości, na rzecz bezpłatnych jednomiesięcznych permis de séjour (zezwolenie na pobyt). Polscy urzędnicy uważali, że Francuzi traktują Polaków gorzej od innych cudzoziemców i upraszali Feliksa Frankowskiego, aby ambasada i PCK rozpoczęły negocjacje z władzami Vichy o lepsze traktowanie Polonii ${ }^{28}$. Współdziałanie między konsulatami a PCK było o tyle istotne, że w momencie, kiedy placówki konsularne nie miały wystarczającej wiedzy o uchodźcach czy starej emigracji, wówczas informacje te nadchodziły z delegatury. Polski Czerwony Krzyż w Tuluzie poinformował np. konsulat w Marsylii o zwolnionych osobach z fabryk francuskich $^{29}$, co było istotne dla ustalenia budżetu pomocowego zarówno przez PCK, jak i konsulaty. Ponadto wspomniane alokacje (12 fr.fr. na dzień) pozwalały na dodatkowe wsparcie finansowe dla uchodźców i odciążały tym samym budżet polskich urzędów ${ }^{30}$. Niemniej jednak ważne było - i tu kategorycznie wzywano do instruowania uchodźców - aby samowolnie nie zmieniali miejsca zamieszkania (zakaz zmiany zamieszkania, dekret wydany 3 lipca $1940 \mathrm{r}$. przez władze francuskie). Nieprzestrzeganie tego dekretu przysparzało wielu problemów, zwłaszcza jeśli chodzi o pobieranie przez uchodźców należnych im alokacji, a na takie działania strona polska nie mogła sobie pozwolić. Inaczej wyglądała sytuacja, jeśli zmiana miejsca zamieszkania była grupowa i zaaranżowana przez PCK $^{31}$.

${ }^{28}$ Ibidem, KRPM do Ambasady RP w Vichy, Marsylia 10 IX 1940 r., k. 32-33.

29 AAN, KRPM, sygn. 464/916, PCK w Tuluzie do KRPM, Tuluza 30 VII 1940 r., k. 190.

${ }^{30}$ BPP, PCK SJJ, sygn. 27, Sprawozdanie z działalności Konsulatu RP w Tuluzie do Ambasady RP w Vichy, Tuluza 2 VIII 1940 r., karty bez paginacji.

${ }^{31}$ Ibidem, sygn. 6, Instrukcja nr 5: Zmiana miejsc pobytu. 
W sierpniu 1940 r. władze francuskie wydały komunikat o przeprowadzeniu rejestru wszystkich uchodźców. Miało to bardzo ważne znaczenie przed repatriacją. PCK wydało rozporządzenie, aby delegaci oraz konsulowie poinformowali uchodźców przebywających na ich terenie o rejestracji i wpisywaniu w odpowiednie rubryki: ancienne adresse i lieu de naissance - słowa „Pologne”. Odnośny komunikat w języku polskim umieszczono w schroniskach, świetlicach, jadłodajniach, delegaturach PCK - oczywiście po uzgodnieniu tego z władzami miejscowymi - tak aby każdy uchodźca mógł się z nim zapoznać. Gdyby jednak jakaś prefektura nie wyraziła zgody, delegaci i konsulowie mieli tłumaczyć to niedopełnienie brakiem znajomości języka francuskiego wśród uchodźców ${ }^{32}$.

Od sierpnia 1940 r., jak już wcześniej wspomniano, konsulaty dostały dyspozycję od ambasady, by przejąć opiekę nad żołnierzami. Na terenie departamentu Bouches-du-Rhône przebywało około 1 tys. oficerów i podoficerów. W Carpiagne umieszczono 1 tys. osób, łącznie z podoficerami, zaś w szpitalu angielskim przebywało 300 żołnierzy. W hotelach w Nicei i Marsylii ulokowano 200 oficerów. Żołnierze przybywali głównie z Lyonu lub z Tuluzy. Do konsulatu w Marsylii zgłaszali się po pomoc ci, którzy uciekli z obozów pracy, lub ci, którzy nie chcieli do nich trafić. Niekiedy fałszowali dokumenty, by otrzymać zasiłek. Większość z nich chciała przedostać się do Anglii. Wśród nich znajdował się element bardzo podatny na agitację komunistyczną lub antyrządową, byli to zwłaszcza ci, którzy nie otrzymali pomocy ze strony władz polskich. Oprócz opieki materialnej, konsulaty, zgodnie z ustaleniami władz zwierzchnich, musiały dodatkowo wystawiać dla nich nowe paszporty (w lipcu wydano ich 730). Żołnierze uważali, że nowe paszporty uchronią ich przed obozem pracy, co było błędnym założeniem, z góry spisanym na niepowodzenie. Od września PCK, po uprzednim uzgodnieniu z ambasadą, przejęło opiekę nad wojennym uchodźctwem i zdemobilizowanymi żołnierzami ${ }^{33}$.

W regionie Prowansji - Lazurowego Wybrzeża, do końca sierpnia przebywało około 300 uchodźców cywilnych, w tej liczbie 150 osób pracujących w wojennych fabrykach francuskich. Około 100 osób przeniosło się do Nicei, a 100 wyjechało do Portugalii. 30 osób, głównie kobiet i dzieci, konsulat umieścił

32 Ibidem, Komunikat nr 4: Rejestracja uchodźców przez władze francuskie, Józef Jakubowski - zastępca delegata prezydium PCK, Tuluza 22 VIII 1940 r., k. 5-6.

33 BPP, PCK SJJ, sygn. 5, PCK do Prezydium Rady Ministrów w Londynie, Tuluza 3 IX 1940 r., k. $127-128$. 
w schroniskach sióstr szarytek i franciszkanek. Pozostali mieszkali w schroniskach, szkołach lub hotelach. W szpitalu angielskim, gdzie mieściło się 300 żołnierzy, opiekę medyczną sprawował nad nimi dr Polaków, zatrudniony z ramienia PCK. Wówczas wszystkie schroniska znajdowały się pod zarządem PCK. W Buis les Baronnies przebywało 50 osób, w Grasse - 40 osób, Juan-les-Pins - 120, a w szpitalu angielskim - 300 osób ${ }^{34}$. Placówki konsularne, tam, gdzie było to możliwe, kierowały uchodźców do tańszych szpitali czy klinik, ale w pewnych przypadkach pokrywały koszty pobytu w szpitalu ze środków konsularnych.

Warto wspomnieć, że niektórzy uchodźcy, mając w pamięci świeżo odciśnięte piętno wojny, nie potrafili sobie poradzić z tułaczką. Zdarzały się przypadki, że wielu z nich prowadziło nieprzyzwoity tryb życia, nie zdając sobie sprawy z konsekwencji, jakie niesie zatarg z władzami lokalnymi i miejscową ludnością (południe Francji - Vichy). Popadanie w konflikty z przedstawicielami władzy na szczeblu lokalnym skutkowało zazwyczaj wydaleniem z Francji. Frankowski, dowiedziawszy się o tego typu incydentach, wydał zalecenie placówkom konsularnym, aby zaprzestały udzielać pomocy osobom szkodzącym interesowi rządu: nie wydawały zapomóg i wyrzucały ze schronisk ${ }^{35}$. Przejawów takich zachowań nie tolerowano, traktując je jako roszczeniowe.

Dnia 19 września 1940 r. minister spraw zagranicznych rządu Vichy Paul Baudouin w rozmowie z Feliksem Frankowskim oznajmił, iż polskie przedstawicielstwa muszą zostać zlikwidowane. Wówczas chargé d’affaires podjął negocjacje z przedstawicielami francuskimi dotyczące formalnej opieki nad Polakami. Sprawa była o tyle pilna, że dotychczas sprawami paszportowo-wizowymi zajmowały się konsulaty, dlatego też niezwłocznie należało podjąć działania zmierzające do kontynuowania tego procesu, jednak na zupełnie innych zasadach. W konsekwencji oznaczało to przejęcie czynności konsularnych przez Biura Polskie. Ich zadaniem było wydawanie dokumentów tożsamości i zaświadczeń, które miały ułatwić Polakom rozwiązywanie spraw osobistych przed władzami francuskimi. Na czele Biur Polskich stał S. Zabiełło - Delegat Rządu na obszar Francji. Biura Polskie powstały w Marsylii, Tuluzie, Lyonie, Nicei,

${ }^{34}$ AAN, KRPM, sygn. 464/835, Sprawozdanie Konsulatu Generalnego RP w Marsylii do Ambasady RP w Vichy, Marsylia 31 VIII 1940 r., k. 33-35.

${ }^{35} \mathrm{Ibidem}$, sygn. 464/835, Delegat Rządu RP dla spraw uchodźstwa polskiego we Francji do konsula w Marsylii, Paryż 5 VI 1940 r., k. 2. 
Monaco, Algierze, Tunisie, Casablance, Dakarze, Tananariwie. Strona francuska - w obawie przed Niemcami - zażądała, aby osoby sprawujące funkcje konsularne przed zerwaniem stosunków dyplomatycznym nie kierowały Biurami Polskimi. Niektórym pracownikom konsulatów i ambasady pozwolono pozostać na południu Francji, przedłużając im paszporty i karty tożsamości, lub umożliwiono natychmiastowy wyjazd, wydając odpowiednie dokumenty - wizy wyjazdowe $\mathrm{e}^{36}$.

Konkludując, południe Francji stało się ważnym ośrodkiem schronienia dla uchodźców cywilnych i wojskowych. Niezmiernie istotne w tej kwestii okazało się nastawienie miejscowych władz francuskich, które odegrały dużą rolę, umożliwiając tworzenie miejsc pobytu. Niewątpliwie kluczowe w tej materii było porozumienie i współpraca z polskimi przedstawicielami rządu. Brak tej kooperacji niezwykle utrudniałby jakiekolwiek starania, ponieważ przedstawiciele miejskich ośrodków na południu Francji również byli zależni od swoich decydentów, którzy podejmowali decyzje, kierując się zmienną dynamiką działań wojennych. Nie zmienia to jednak faktu, że w miarę możliwości obie strony starały się dopomóc uchodźcom, tak aby mogli chociaż przez moment poczuć namiastkę bezpieczeństwa, które później, po czerwcu 1940 r., okazało się względne.

\section{BIBLIOGRAFIA}

\section{Źródła archiwalne}

Archiwum Akt Nowych w Warszawie

Konsulat Rzeczypospolitej Polskiej w Marsylii, sygn. 464/835; 464/916.

Biblioteka Polska w Paryżu

Archiwum Polskiego Czerwonego Krzyża we Francji ze spuścizny Józefa Jakubowskiego, sygn. 5, 6, 22, 27.

Instytut Polski i Muzeum im. Generała Władysława Sikorskiego w Londynie

Armia Polska we Francji, sygn. A.IV.4/1/37.

Polski Czerwony Krzyż we Francji, sygn. PRM-K/6.

${ }^{36}$ A. PaChowicz, op. cit., s. 34-36. 


\section{Opracowania}

Ambrochowicz-Gajownik A., W cieniu Lazurowego Wybrzeża. Konsulat polski w Marsylii 1919-1940, Warszawa 2019.

Batowski H., Polska dyplomacja na obczyźnie 1939-1941, Kraków 1991.

Gmurczyk-Wrońska M., Polska - niepotrzebny aliant Francji? (Francja wobec Polski w latach 1938-1944), Warszawa 2003.

Hall A., Naród i państwo w myśli politycznej Charles'a de Gaulle’a, Warszawa 2005.

Kania K., Edward Bernard Raczyński 1891-1993. Dyplomata i polityk, Warszawa 2014.

Pachowicz A., Towarzystwo Opieki nad Polakami we Francji 1941-1944, Toruń 2013.

Pestkowska M., Za kulisami rzadu polskiego na emigracji, Warszawa 2000.

Rutkowski T.P., Stanistaw Kot 1885-1975. Biografia polityczna, Warszawa 2000.

Vinen R., France 1934-1970, New York 1996.

Wyrwa T., Bezdroża dziejów Polski. Kraj i emigracja po 1 września 1939 r., Lublin 2000.

Wyrwa T., Wtadze RP we Francji. Odbudowa wtadz Rzeczypospolitej w Paryżu i Angers wrzesień 1939 - czerwiec 1940, [w:] Wtadze RP na Obczyźnie podczas II wojny światowej 1939-1945, red. Z. Błażyński, Londyn 1994, s. 71.

Zabiełło S., Na posterunku we Francji, Warszawa 1967.

Zabiełło S., O rząd i granice. Walka dyplomatyczna o sprawe polska w II wojnie światowej, Warszawa 1986.

\section{Anna Ambrochowicz-Gajownik}

\section{MUNICIPAL CENTERS OF SOUTHERN FRANCE AS A PLACE OF REFUGE FOR POLISH REFUGEES BETWEEN 1939 AND 1940}

Summary. The south of France has become an important hub for civilian and military refugees. The activities of the Polish authorities covered over 5000 refugees from Poland, as well as demobilized soldiers, of which there were 12 000. Evacuation to France was carried out by sea and land. From October 1939 until April 194031727 people passed through the border crossings. By May 1940, 33120 people had been evacuated. Special shelters and kitchens for refugees were created in various centers of southern France, and some were placed in hotels. Efforts were also made to create day-rooms and small workplaces. Moreover, all help was given to Polish soldiers and their families. Pre-war emigration was also taken care of. Gaining places for refugees would not be possible without the cooperation of local authorities. The Polish consular service operating until September 1940, as well as the Polish Red Cross delegations operating in Toulouse, Marseille and Nice played a key role in caring for refugees in this period. The defeat of France brought changes both for the Polish government and for refugees.

Keywords: Provence-Cote d'Azur, Toulouse, Polish consular service, Polish-French relations, Polish Red Cross, World War II 